\title{
Synthesis of 5-(trifluoromethyl)-5H-chromeno[3,4-b]pyridines from 3-nitro-2-(trifluoromethyl)-2H-chromenes and aminoenones derived from acetylacetone and cyclic amines
}

\author{
Vladislav Yu. Korotaev, Alexey Yu. Barkov, Vyacheslav Ya. Sosnovskikh* \\ Department of Chemistry, Ural Federal University, pr. Lenina 51, 620000 Ekaterinburg, Russia
}

\section{A R T I C L E I N F O}

\section{Article history:}

Received 15 February 2013

Revised 20 March 2013

Accepted 28 March 2013

Available online 11 April 2013

\section{Keywords:}

3-Nitro-2H-chromenes

Push-pull enamines

Michael addition

Chromanes

Chromeno[3,4-b]pyridines

\begin{abstract}
A B S T R A C T
Reactions of 3-nitro-2H-chromenes with aminoenones derived from acetylacetone and cyclic amines proceed diastereoselectively to give functionalized 2,3,4-trisubstituted chromanes as a result of nucleophilic addition of the vinylogous $\beta$-methyl group at the $C-4$ atom of the chromene system. From these compounds, under acidic conditions, 5-(trifluoromethyl)-5H-chromeno[3,4-b]pyridines and 4-acetoacetonyl-3-nitro-2-(trichloromethyl/phenyl)chromanes, depending on the substituent at the 2-position, were obtained in moderate to good yields.
\end{abstract}

(c) 2013 Elsevier Ltd. All rights reserved.
Many derivatives of chromane (3,4-dihydro-2H-1-benzopyran) and $2 \mathrm{H}$-chromene (2H-1-benzopyran) are natural compounds that are widely abundant in the plant kingdom. ${ }^{1}$ Some of these, as well as a series of synthetic $2 \mathrm{H}$-chromenes, have found use as pesticides and promising drugs. ${ }^{2} 3$-Nitro- $2 \mathrm{H}$-chromenes, as conjugated nitroolefins, possess unique chemical reactivity in both nucleophilic and cycloaddition reactions because of their reactive double bond. As a result, these compounds have attracted attention as excellent building blocks for the preparation of various more complex heterocyclic compounds. ${ }^{3}$ In particular, 3-nitro- $2 H$-chromenes react with diverse $\mathrm{C}^{-}, \mathrm{N}-, \mathrm{S}-$, and $\mathrm{P}$-nucleophiles to give a wide range of substituted ${ }^{4}$ and fused ${ }^{5}$ chromanes. Recently, the reactions of 2 -aryl-3-nitro- $2 H$-chromenes with $\alpha, \alpha$-dicyanoolefins in the presence of triethylamine, leading to the preparation of 6-aryl-6H-dibenzo[ $b, d]$ pyran derivatives, were reported. ${ }^{6}$ At the same time, to the best of our knowledge, very little information is available on the reactions of 3-nitro- $2 \mathrm{H}$-chromenes with push-pull enamines. ${ }^{7}$ It has been reported that 2-aryl-3-nitro- $2 \mathrm{H}$-chromenes react with methyl $\beta$-methylaminocrotonate to give mixtures of the addition product, methyl 3-methylamino-2-(2-aryl-3-nitrochroman-4-yl)2-butenoate, and 1-benzopyrano[3,4-b]pyrrole, formed via the Grob cyclization, ${ }^{8}$ whereas their reactions with ethyl $\beta$-morpholinocrotonate took an entirely different course and gave ethyl 3morpholino-4-(2-aryl-3-nitrochroman-4-yl)-2-butenoates. ${ }^{9}$ The

\footnotetext{
* Corresponding author. Fax: +7 3432615978.

E-mail address: vyacheslav.sosnovskikh@usu.ru (V.Y. Sosnovskikh).
}

latter result belongs to a rare case, where the reaction proceeded not at the more nucleophilic $\alpha$-position of an enamino ester, but at the vinylogous $\beta$-methyl group. This is of particular interest because it results in the formation of a functionalized chromane system, which has not been reported previously.

Within the framework of a research program on the synthetic opportunities offered by 3-nitro-2-trihalomethyl-2H-chromenes $\mathbf{1}$ for the preparation of organic molecules of potential interest in biomedicinal chemistry and materials science, ${ }^{5}$ we examined the behavior of compounds $\mathbf{1}$ in reactions with the push-pull enamines derived from acetylacetone and cyclic amines, namely (E)-4-morpholino- and (E)-4-piperidinopent-3-en-2-ones, with the purpose of studying the structures and acid-catalyzed transformations of the addition products $\mathbf{2}$. The present communication describes a new type of pyridine ring annulation, which consists of the conversion of compounds 2 into 5-(trifluoromethyl)$5 H$-chromeno[3,4-b]pyridines 4 , and demonstrates the dramatic effect of the trifluoromethyl group on the reaction pathway.

We found that the reaction of chromenes 1 with 4-morpholinoand 4-piperidinopent-3-en-2-ones in dry acetonitrile at room temperature for $2-48 \mathrm{~h}$ resulted in the stereoselective formation of 2,3,4-trisubstituted chromanes $\mathbf{2 a}$-i i in $42 \%-83 \%$ yields as single diastereomeric products with cis-trans-configuration $\left({ }^{3} \mathrm{~J}_{\mathrm{H} 2, \mathrm{H} 3}=\right.$ $\left.{ }^{3} J_{\mathrm{H} 3, \mathrm{H} 4}=1.5 \mathrm{~Hz}\right)$ at the $\mathrm{C}(2)-\mathrm{C}(3)$ and $\mathrm{C}(3)-\mathrm{C}(4)$ bonds, respectively, and with $E$-configuration at the double bond (Scheme 1, Table 1$).{ }^{10}$ The stereochemistry of the products was confirmed by an X-ray diffraction study of crystals of 2a (Fig. 1). ${ }^{11}$ 


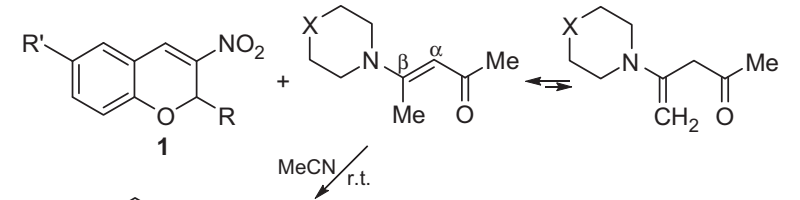

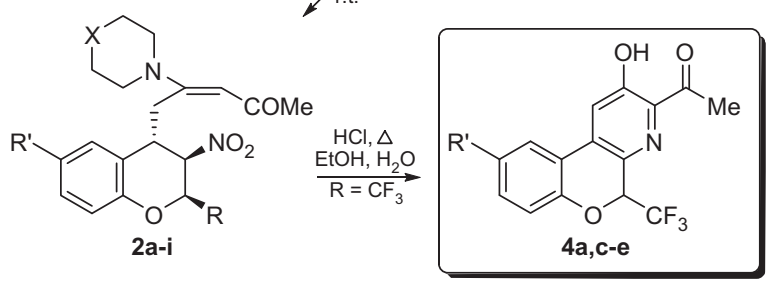
$\mathrm{HCl}, \Delta \downarrow \mathrm{R}=\mathrm{CCl}_{3}, \mathrm{Ph}$<smiles>[R]c1ccc2c(c1)[C@@H](C/C(O)=C/C(C)=O)[C@@H]([N+](=O)[O-])C([R])O2</smiles>

Scheme 1. Synthesis of compounds 2-4.

Table 1

Synthesis of compounds $\mathbf{2 - 4}$

\begin{tabular}{llllllll}
\hline $\mathrm{R}$ & $\mathrm{R}^{\prime}$ & $\mathrm{X}$ & Product $\mathbf{2}$ & Time $(\mathrm{h})$ & Yield (\%) & Product 3, 4 & Yield $(\%)$ \\
\hline $\mathrm{CF}_{3}$ & $\mathrm{H}$ & $\mathrm{CH}_{2}$ & $\mathbf{2 a}$ & 2 & 71 & $\mathbf{4 a}$ & 34 \\
$\mathrm{CF}_{3}$ & $\mathrm{H}$ & $\mathrm{O}$ & $\mathbf{2 b}$ & 5 & 83 & $\mathbf{4 a}$ & 33 \\
$\mathrm{CF}_{3}$ & $\mathrm{Br}$ & $\mathrm{O}$ & $\mathbf{2 c}$ & 3 & 80 & $\mathbf{4 c}$ & 46 \\
$\mathrm{CF}_{3}$ & $\mathrm{NO}_{2}$ & $\mathrm{O}$ & $\mathbf{2 d}$ & 6 & 70 & $\mathbf{4 d}$ & 42 \\
$\mathrm{CF}_{3}$ & $\mathrm{MeO}$ & $\mathrm{O}$ & $\mathbf{2 e}$ & 48 & 64 & $\mathbf{4 e}$ & 34 \\
$\mathrm{CCl}_{3}$ & $\mathrm{H}$ & $\mathrm{O}$ & $\mathbf{2 f}$ & 30 & 42 & $\mathbf{3} \mathbf{f}^{\mathrm{a}}$ & 56 \\
$\mathrm{CCl}_{3}$ & $\mathrm{Br}$ & $\mathrm{CH}_{2}$ & $\mathbf{2 g}$ & 7 & 56 & $\mathbf{3 g}^{\mathrm{b}}$ & 63 \\
$\mathrm{CCl}_{3}$ & $\mathrm{Br}$ & $\mathrm{O}$ & $\mathbf{2 h}$ & 21 & 52 & $\mathbf{3 g}$ & 66 \\
$\mathrm{Ph}$ & $\mathrm{H}$ & $\mathrm{O}$ & $\mathbf{2 i}$ & 7 & 62 & $\mathbf{3 i}^{\mathrm{c}}$ & 60 \\
\hline
\end{tabular}

a $\mathbf{3 f}: \mathbf{3}^{\prime} \mathbf{f}=88: 12$.

b $\mathbf{3 g}: \mathbf{3}^{\prime} \mathbf{g}=91: 9$.

c $\mathbf{3 i}: \mathbf{3}^{\prime} \mathbf{i}=69: 31$.

The reaction time varied according to the nature of the chromene molecule. In general, $2-\mathrm{CF}_{3}-\mathrm{Chromenes}$ were more reactive than 2- $\mathrm{CCl}_{3}$ - and 2-Ph-chromenes; conjugate addition of an enamine to a $\mathrm{CF}_{3}$-chromene containing an electron-donating $\mathrm{MeO}$ group required a longer period of time for completion of the reaction, while electron-withdrawing groups $\left(\mathrm{Br}, \mathrm{NO}_{2}\right)$ required relatively short reaction times. Addition of push-pull enamines at the vinyl-

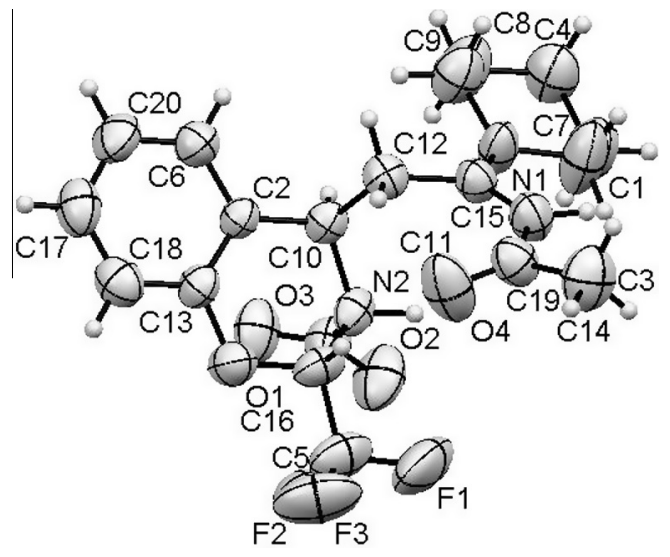

Figure 1. X-ray crystal structure of cis-trans-2a (ORTEP drawing, 50\% probability level). ogous $\beta$-Me group possibly results from the $E$-configuration of the starting enamines, which hinders the approach of the $\alpha-C$ atom to the activated double bond of the chromene system.

Next we examined the acid hydrolysis of enamino ketones $2 \mathbf{a}-\mathbf{i}$ in aqueous ethanol at reflux in the presence of concentrated $\mathrm{HCl}$. As expected, hydrolysis of compounds $\mathbf{2 f}-\mathbf{i}$ successfully removed the amino function to give interesting acetoacetonyl derivatives 3f, $\mathbf{g}$, and $\mathbf{i}$ as a mixture of keto-enol tautomers $\mathbf{3}$ and $\mathbf{3}^{\prime}$ in 56\%$66 \%$ yields, with the same configuration (9\%-31\% of diketo form $\left.\mathbf{3}^{\prime}\right)$. As for the $2-\mathrm{CF}_{3}-$ chromanes $\mathbf{2 a}-\mathbf{e}$, there was a marked difference in their reactivity toward acid hydrolysis. Under the same conditions, instead of the corresponding acetoacetonyl derivatives 3, we obtained 5-(trifluoromethyl)-5H-chromeno[3,4-b]pyridines 4a, c-e in 33\%-46\% isolated yields (Scheme 1, Table 1). The structures of compounds 3 and $\mathbf{4}$ were established by IR, ${ }^{1} \mathrm{H},{ }^{19} \mathrm{~F}$, and ${ }^{13} \mathrm{C}$ NMR spectroscopy as well as by elemental analysis. ${ }^{12}$

These results indicate that the nature of the substituent at the 2-position influences the course of the acid-catalyzed hydrolysis of 2 , which in the case of a $\mathrm{CF}_{3}$ group took an unexpected direction compared with the reaction of nonfluorinated chromanes. It is important to note that this new cyclization process tolerates both electron-donating $(\mathrm{MeO})$ and electron-withdrawing $\left(\mathrm{Br}, \mathrm{NO}_{2}\right)$ substituents on the benzene ring. Moreover, unlike previously known approaches for the synthesis of quinolines from nitro derivatives, ${ }^{13}$ this reaction does not require any reducing agent or chromatographic purification of the final products, and thereby greatly facilitates the preparation of the target chromenopyridines 4 .

We can assume that cyclization of $\mathbf{2}$ into $\mathbf{4}$ was possible due to the high $\mathrm{C}-\mathrm{H}$ acidity of the $\mathrm{H}-2$ in aci-form $\mathbf{A}$, which could be easily abstracted by the base to form $\mathbf{B}$ (nitrone- $N$-hydroxyenamine prototropic tautomeric equilibria through a $[1,4]-\mathrm{H}$ shift ${ }^{14}$ ), followed by dehydration of intermediate $\mathbf{B}$ into the corresponding $\alpha$-nitrosoalkene $\mathbf{C}$. Intramolecular nucleophilic attack of the side-chain enol on the nitroso group followed by dehydration results in the intermediate $\mathbf{D}$, which undergoes a double [1,3]-H shift to give chromenopyridines 4 (Scheme 2). The lack of such reactivity in the case of compounds $\mathbf{2} \mathbf{f}-\mathbf{i}$ was apparently due to the lower acidity of the $\mathrm{H}-2$ proton. It should be noted that a similar $[1,4]-\mathrm{H}$ shift has been previously observed by us in the spontaneous ring-contraction-rearrangement of $\mathrm{CF}_{3}$-containing 1,2-oxazine $\mathrm{N}$-oxides into 1 -pyrroline $\mathrm{N}$-oxides. ${ }^{15}$

The main information for the characterization of compounds 4 was obtained from the ${ }^{1} \mathrm{H}$ NMR spectra, which showed no methylene signal, a result consistent with the pyridine structure. The most downfield shifted signal was assigned to the hydroxyl proton, which appeared as a singlet at $\delta 12.0$ in $\mathrm{CDCl}_{3}$, the singlet

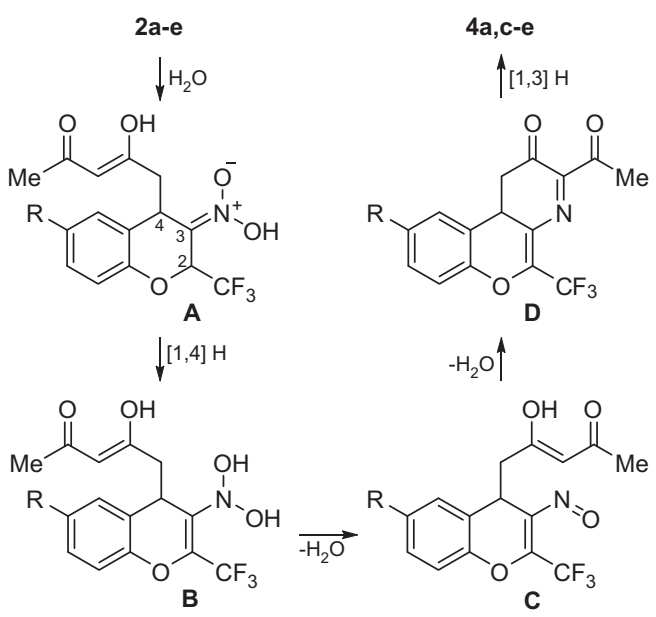

Scheme 2. Mechanism of the formation of chromeno[3,4-b]pyridines 4 . 
at $\delta$ 7.58-7.77 was due to the resonance of the pyridine $\mathrm{H}-1$ proton; assignment of all the signals was achieved by $2 \mathrm{D}{ }^{1} \mathrm{H}-{ }^{13} \mathrm{C}$ HSQC, and HMBC experiments. In the $2 \mathrm{D}{ }^{1} \mathrm{H}-{ }^{15} \mathrm{~N}$ HMBC spectrum of 4c, a signal was observed at $\delta 316.9$ from liquid $\mathrm{NH}_{3}$, indicating that the $\mathrm{N}$ was present in a pyridine ring. ${ }^{16}$ In addition, the $\mathrm{CF}_{3}$ group in the ${ }^{19} \mathrm{~F}$ NMR spectra of chromenopyridines $\mathbf{4}$ manifested itself as a doublet at $\delta 85.0-85.5(J=7.0-7.3 \mathrm{~Hz})$.

In conclusion, we have shown, for the first time, that the reaction of 3-nitro- $2 \mathrm{H}$-chromenes with push-pull enamines affords linear enamines with the chromanyl moiety, acid hydrolysis of which gave either $5 H$-chromeno[3,4-b]pyridines or 4-(acetoacetonyl)chromanes, depending on the nature of the substituent at $\mathrm{C}-2$. When this substituent was a $\mathrm{CF}_{3}$ group, a novel synthesis of fused pyridines followed, while acid hydrolysis of $\mathrm{CCl}_{3}$ - and Ph-containing derivatives proceeded in the expected manner to give interesting polyfunctional chromane derivatives. Further studies on the synthetic scope of these reactions are now in progress.

\section{Acknowledgment}

This work was supported financially by the Russian Foundation for Basic Research (Grant 11-03-00126).

\section{References and notes}

1. (a) Schweizer, E. E.; Meeder-Nycz, D. In The Chemistry of Heterocyclic Compounds: Chromenes, Chromanones, and Chromones; Ellis, G. P., Ed.; Wiley: New York, 1977; Vol. 31; (b) The Chemistry of Heterocyclic Compounds: Chromans and Tocopherols; Ellis, G. P., Lockhard, I. M., Eds.; Wiley: New York, 1981; Vol. 36; (c) Horton D. A.; Bourne, G. T.; Smythe, M. L. Chem. Rev. 2003, $103,893$.

2. (a) Bowers, W. S.; Ohta, T.; Cleere, J. S.; Marsella, P. A. Science 1976, 193, 542; (b) Bergmann, R.; Gericke, R. J. Med. Chem. 1990, 33, 492; (c) Burrell, G.; Cassidy, F.; Evans, J. M.; Lightowler, D.; Stemp, G. J. Med. Chem. 1990, 33, 3023; (d) Gericke, R.; Harting, J.; Lues, I.; Schittenhelm, C. J. Med. Chem. 1991, 34, 3074.

3. (a) Ono, N. The Nitro Group in Organic Synthesis; Wiley-VCH: New York, 2001; (b) Yoshikoshi, A.; Miyashita, M. Acc. Chem. Res. 1985, 18, 284; (c) Bhanja, C.; Jena, S.; Nayak, S.; Mohapatra, S. Beilstein J. Org. Chem. 2012, 8, 1668.

4. (a) Korotaev, V. Y.; Sosnovskikh, V. Y.; Kutyashev, I. B.; Kodess, M. I. Lett. Org. Chem. 2005, 2, 616; (b) Korotaev, V. Y.; Sosnovskikh, V. Y.; Kutyashev, I. B.; Kodess, M. I. Izv. Akad. Nauk, Ser. Khim. 2006, 309 (Russ. Chem. Bull., Int. Ed. 2006, 55, 317); (c) Korotaev, V. Y.; Sosnovskikh, V. Y.; Kutyashev, I. B.; Kodess, M. I. Izv. Akad. Nauk, Ser. Khim. 2006, 1945 (Russ. Chem. Bull., Int. Ed. 2006, 55, 2020); (d) Korotaev, V. Y.; Kutyashev, I. B.; Sosnovskikh, V. Y.; Kodess, M. I. Mendeleev Commun 2007, 17, 52; (e) Korotaev, V. Y; Sosnovskikh, V. Y.; Kutyashev, I. B. Izv. Akad. Nauk, Ser. Khim. 2007, 1985 (Russ. Chem. Bull., Int. Ed. 2007, 56, 2054); (f) Biswas, S.; Maulik, P. R.; Gupta, R. C.; Seth, M.; Bhaduri, A. P. Acta Crystallogr., Sect. C 1996, 52, 1036; (g) Lin, C.; Hsu, J.; Sastry, M. N. V.; Fang, H.; Tu, Z.; Liu, J.-T.; Yao, C.-F. Tetrahedron 2005, 61, 11751; (h) Ono, N.; Banshou, N.; Ioto, S.; Murashima, T.; Ogawa, T. J. Heterocycl. Chem. 1997, 34, 1243.

5. (a) Korotaev, V. Y.; Sosnovskikh, V. Y.; Barabanov, M. A.; Yasnova, E. S.; Ezhikova, M. A.; Kodess, M. I.; Slepukhin, P. A. Tetrahedron 2010, 66, 1404; (b) Korotaev, V. Y.; Sosnovskikh, V. Y.; Kutyashev, I. B.; Barkov, A. Y.; Shklyaev, Y. V. Tetrahedron Lett. 2008, 49, 5376; (c) Korotaev, V. Y.; Sosnovskikh, V. Y.; Barkov, A. Y.; Slepukhin, P. A.; Ezhikova, M. A.; Kodess, M. I.; Shklyaev, Y. V. Tetrahedron 2011, 67, 8685.

6. (a) Li, P.; Luo, L.-L.; Li, X.-S.; Xie, J.-W. Tetrahedron 2010, 66, 7590; (b) Guo, Z.W.; Li, X.-S.; Zhu, W.-D.; Xie, J.-W. Eur. J. Org. Chem. 2012, 6924.

7. Kostyuk, A. N.; Volochnyuk, D. M.; Sibgatulin, D. A. Synthesis 2008, 161.

8. Gupta, R. C.; Seth, M.; Bhaduri, A. P. J. Indian Chem. 1991, 30B, 297.

9. Korotaev, V.Y.; Barkov, A.Y.; Sokovnina, A.A.; Sosnovskikh, V.Y. Mendeleev Commun. 2013, 23, N 3.

10. General procedure for the synthesis of chromanes $\mathbf{2}$. A mixture of chromene $\mathbf{1}$ $(1.0 \mathrm{mmol})$ and (E)-4-morpholino(piperidino)pent-3-en-2-one $(0.17 \mathrm{~g}$,
$1.0 \mathrm{mmol}$ ) in dry $\mathrm{MeCN}$ was stirred at room temperature for several hours (Table 1). The solid that formed was filtered and recrystallized from $\mathrm{CH}_{2} \mathrm{Cl}_{2}$ / hexane $(1: 2)$ to give compound 2 as a white powder.

(E)-5-[(2R*,3R*,4S*)-4-Morpholino-3-nitro-2-(trifluoromethyl)-3,4-dihydro-2Hchromen-4-yll-3-penten-2-one (2b). Yield $0.35 \mathrm{~g}$ (83\%), mp $164-165{ }^{\circ} \mathrm{C}$ (dec.). IR (KBr): $1655,1632,1549,1490,1448,1374 \mathrm{~cm}^{-1} ;{ }^{1} \mathrm{H}$ NMR $\left(400 \mathrm{MHz}, \mathrm{CDCl}_{3}\right) \delta$ 2.13 (s, 3H, Me), 2.75 (dd, $1 \mathrm{H}, \mathrm{CHH}, J=14.6,2.6 \mathrm{~Hz}$ ), $3.30\left(\mathrm{dt}, 2 \mathrm{H}, \mathrm{N}(\mathrm{CHH})_{2}\right.$, $J=12.9,4.9 \mathrm{~Hz}), 3.30-3.40\left(\mathrm{~m}, 3 \mathrm{H}, \mathrm{H}-4, \mathrm{~N}(\mathrm{CHH})_{2}\right), 3.76\left(\mathrm{t}, 4 \mathrm{H}, \mathrm{O}\left(\mathrm{CH}_{2}\right)_{2}\right.$, $J=4.9 \mathrm{~Hz}), 4.23(\mathrm{br} \mathrm{t}, 1 \mathrm{H}, \mathrm{CHH}, J=13.3 \mathrm{~Hz}), 5.16(\mathrm{br} \mathrm{s}, 1 \mathrm{H}, \mathrm{H}-3), 5.27$ (br q, $1 \mathrm{H}, \mathrm{H}-2, J=6.0 \mathrm{~Hz}), 5.47(\mathrm{~s}, 1 \mathrm{H},=\mathrm{CH}), 7.02-7.10(\mathrm{~m}, 2 \mathrm{H}, \mathrm{H}-6, \mathrm{H}-8), 7.17$ (br d, $1 \mathrm{H}, \mathrm{H}-5, J=7.3 \mathrm{~Hz}), 7.22-7.30(\mathrm{~m}, 1 \mathrm{H}, \mathrm{H}-7) ;{ }^{13} \mathrm{C} \mathrm{NMR}\left(126 \mathrm{MHz}, \mathrm{CDCl}_{3}\right) \delta 32.0$, $32.5,38.6,47.0,66.2,70.7\left(\mathrm{q}, \mathrm{C}-2,{ }^{2} J_{\mathrm{C}} \mathrm{F}=34.1 \mathrm{~Hz}\right), 77.6,101.8,117.6,120.7$, $122.3\left(\mathrm{q}, \mathrm{CF}_{3},{ }^{1} J_{\mathrm{C}, \mathrm{F}}=280.8 \mathrm{~Hz}\right), 122.8,128.3,128.9,152.0,158.3,196.5(\mathrm{C}=\mathrm{O})$; ${ }^{19} \mathrm{~F}$ NMR (376 MHz, $\left.\mathrm{CDCl}_{3}\right) \delta 86.8\left(\mathrm{~d}, \mathrm{CF}_{3}, J=6.0 \mathrm{~Hz}\right)$. Anal. calcd for $\mathrm{C}_{19} \mathrm{H}_{21} \mathrm{~F}_{3} \mathrm{~N}_{2} \mathrm{O}_{5}$ : C, 55.07; H, 5.11; N, 6.76. Found: C, 54.90; H, 4.97; N, 6.82.

11. X-ray diffraction study of compound 2a. Diffraction data were collected at $295 \mathrm{~K}$ on an Xcalibur 3 automatic single-crystal diffractometer (graphitemonochromated MoK $\alpha$ radiation, $\omega$-scans). The structure was solved by direct method and refined by the full-matrix least-squares method using the SHELX97 program package. ${ }^{17}$ The $\mathrm{H}$ atoms were located geometrically using the riding model. Crystal data for 2a: $\mathrm{C}_{20} \mathrm{H}_{23} \mathrm{~F}_{3} \mathrm{~N}_{2} \mathrm{O}_{4}, M=412.40$, monoclinic crystals, space group $C 2 / c, a=19.979(2), b=10.1081(8), c=20.1833(19) \AA$, $\alpha=\gamma=90.00, \quad \beta=96.442(8)^{\circ}, \quad V=4050.2(6) \AA^{3}, \quad Z=8, \quad d_{\text {calcd }}=1.353 \mathrm{~g} / \mathrm{cm}^{3}$. $\mu=0.112 \mathrm{~mm}^{-1}, \quad F(000)=1728$. Crystallographic data for compound 2a (CCDC 924323) have been deposited at the Cambridge Crystallographic Data Centre, 12 Union Road, Cambridge CB2 1EZ, UK.

12. General procedures for the synthesis of compounds $\mathbf{3}$ and $\mathbf{4}$. The corresponding chromane $2(1.0 \mathrm{mmol})$ was refluxed in a mixture of EtOH $(4 \mathrm{~mL}), \mathrm{H}_{2} \mathrm{O}(2 \mathrm{~mL})$, and conc. $\mathrm{HCl}(0.2 \mathrm{~mL})$ with vigorous stirring for $6 \mathrm{~h}$. The reaction mixture was cooled to room temperature and the solid that formed was filtered, washed with $\mathrm{H}_{2} \mathrm{O}(2 \times 1 \mathrm{~mL})$, dried at $70^{\circ} \mathrm{C}$, and recrystallized from $\mathrm{CH}_{2} \mathrm{Cl}_{2} /$ hexane ( $1: 2$ ) (for 3 , a white powder) or $\mathrm{MeOH}$ (for $\mathbf{4}$, colorless needles).

$\left(2 R^{*}, 3 R^{*}, 4 S^{*}\right)$-1-[6-Bromo-3-nitro-2-(trichloromethyl)-3,4-dihydro-2H-chromen4-yl]-2,4-pentanedione (3g). Yield $0.30 \mathrm{~g}(63 \%), \mathrm{mp} 140-141^{\circ} \mathrm{C}$. IR (KBr): 1715 , 1626, 1601, 1552, 1480, 1412, $1366 \mathrm{~cm}^{-1} ;{ }^{1} \mathrm{H}$ NMR $\left(500 \mathrm{MHz}, \mathrm{CDCl}_{3}\right)$ enol $\mathbf{3 g}$ (91\%) $\delta 2.11(\mathrm{~s}, 3 \mathrm{H}, \mathrm{Me}), 2.57(\mathrm{dd}, 1 \mathrm{H}, \mathrm{CHH}, J=16.4,10.7 \mathrm{~Hz}), 2.90(\mathrm{dd}, 1 \mathrm{H}, \mathrm{CHH}$, $J=16.4,4.2 \mathrm{~Hz}$ ), 3.87 (dd, $1 \mathrm{H}, \mathrm{H}-4, J=10.7,4.2 \mathrm{~Hz}$ ), 4.50 (br s, $1 \mathrm{H}, \mathrm{H}-3$ ), 5.53 (s, $1 \mathrm{H}, \mathrm{H}-2), 5.71(\mathrm{~s}, 1 \mathrm{H},=\mathrm{CH}), 7.01(\mathrm{~d}, 1 \mathrm{H}, \mathrm{H}-8, J=8.8 \mathrm{~Hz}), 7.33(\mathrm{~d}, 1 \mathrm{H}, \mathrm{H}-5$, $J=2.2 \mathrm{~Hz}$ ), 7.38 (dd, $1 \mathrm{H}, \mathrm{H}-7, J=8.8,2.2 \mathrm{~Hz}$ ); diketo $3^{\prime} \mathbf{g}(9 \%) \delta 2.76(\mathrm{~s}, 3 \mathrm{H}, \mathrm{Me})$, 2.95-3.06 (m, 2H, CH $), 3.63(\mathrm{~d}, 1 \mathrm{H}, \mathrm{CHH}, J=15.8 \mathrm{~Hz}), 3.70(\mathrm{~d}, 1 \mathrm{H}, \mathrm{CHH}$, $J=15.8 \mathrm{~Hz}$ ), 3.96 (dd, $1 \mathrm{H}, \mathrm{H}-4, J=8.2,5.5 \mathrm{~Hz}), 4.51$ (br s, $1 \mathrm{H}, \mathrm{H}-3), 5.61$ (d, $1 \mathrm{H}$, $\mathrm{H}-2, J=1.5 \mathrm{~Hz}$ ), 7.00 (d, $1 \mathrm{H}, \mathrm{H}-8, J=8.9 \mathrm{~Hz}), 7.28$ (d, $1 \mathrm{H}, \mathrm{H}-5, J=2.3 \mathrm{~Hz}), 7.33$ (dd, $1 \mathrm{H}, \mathrm{H}-7, J=8.9,2.3 \mathrm{~Hz}) ;{ }^{13} \mathrm{C}$ NMR $\left(126 \mathrm{MHz} \mathrm{CDCl}_{3}\right)$ enol $3 g$ g 24.2, 36.9, $45.6,78.8,80.5,95.2,100.6,115.4,119.1,122.9,131.3,131.8,151.8,189.9$, 190.1; diketo $\mathbf{3}^{\prime} \mathbf{g} \delta 31.1,35.3,50.1,56.9,78.7,80.6,100.5,115.3,119.2,122.8$, $131.1,131.7,151.9,200.2$, 202.3. Anal. calcd for $\mathrm{C}_{15} \mathrm{H}_{13} \mathrm{BrCl}_{3} \mathrm{NO}_{5}: \mathrm{C}, 38.05 ; \mathrm{H}$, 2.77; N, 2.96. Found: C, 37.75; H, 2.59; N, 2.95.

1-\{9-Bromo-2-hydroxy-5-(trifluoromethyl)-5H-chromeno[3,4-b]pyridin-3-

$y$ l \}ethanone (4c). Yield 0.18 g (46\%), mp 189-190 ${ }^{\circ} \mathrm{C}$. IR (KBr): $1657,1601,1484$, 1399, 1264, $1221 \mathrm{~cm}^{-1}$; ${ }^{1} \mathrm{H}$ NMR (500 MHz, $\left.\mathrm{CDCl}_{3}\right) \delta 2.76(\mathrm{~s}, 3 \mathrm{H}, \mathrm{Me}), 5.60(\mathrm{q}$, $1 \mathrm{H}, \mathrm{H}-5, J=7.1 \mathrm{~Hz}), 7.00(\mathrm{~d}, 1 \mathrm{H}, \mathrm{H}-7, J=8.8 \mathrm{~Hz}), 7.47$ (dd, $1 \mathrm{H}, \mathrm{H}-8, J=8.8$ $2.1 \mathrm{~Hz}), 7.58(\mathrm{~s}, 1 \mathrm{H}, \mathrm{H}-1), 7.79(\mathrm{~d}, 1 \mathrm{H}, \mathrm{H}-10, \mathrm{~J}=2.1 \mathrm{~Hz}), 11.93(\mathrm{~s}, 1 \mathrm{H}, \mathrm{OH}) ;{ }^{13} \mathrm{C}$ NMR (126 MHz, $\left.\mathrm{CDCl}_{3}\right) \delta 25.7(\mathrm{Me}), 75.2\left(\mathrm{q}, \mathrm{C}-5,{ }^{2} J_{\mathrm{C}, \mathrm{F}}=31.6 \mathrm{~Hz}\right), 115.8(\mathrm{C}-9)$, $118.7(\mathrm{C}-1), 119.6(\mathrm{C}-7), 119.8(\mathrm{C}-10 \mathrm{a}), 123.0\left(\mathrm{q}, \mathrm{CF}_{3}, J_{\mathrm{C}, \mathrm{F}}=286.9 \mathrm{~Hz}\right), 127.1(\mathrm{C}-$ 10), 130.9 (C-10b), 134.8 (C-4a), 135.1 (C-8), 135.6 (C-3), 151.6 (C-6a), 159.6 $(\mathrm{C}-2), 206.5(\mathrm{C}=\mathrm{O}) ;{ }^{19} \mathrm{~F}$ NMR $\left(471 \mathrm{MHz}, \mathrm{CDCl}_{3}\right) \delta 85.2\left(\mathrm{~d}, \mathrm{CF}_{3}, J_{\mathrm{F}, \mathrm{H}}=7.1 \mathrm{~Hz}\right) ;{ }^{15} \mathrm{~N}$ NMR (51 MHz, CDCl $)_{3} \delta 316.9$; MS (EI): $m / z 389\left[{ }^{81} \mathrm{Br}, \mathrm{M}+1\right]^{+}(32), 387\left[{ }^{79} \mathrm{Br}\right.$, $\mathrm{M}+1]^{+}(32), 320\left[\mathrm{M}+1-\mathrm{CF}_{3}\right]^{+}(100), 318\left[\mathrm{M}-1-\mathrm{CF}_{3}\right]^{+}(100), 290\left[\mathrm{M}+1-\mathrm{CF}_{3}-\mathrm{CO}^{+}\right.$ (18), 196 (17), 169 (13), 140 (19), 113 (24), 63 (21), 43 [Ac] $]^{+}$(79). Anal. calcd for $\mathrm{C}_{15} \mathrm{H}_{9} \mathrm{BrF}_{3} \mathrm{NO}_{3}$ : C, 46.42; H, 2.34; N, 3.61. Found: C, 46.18; H, 2.48; N, 3.55.

13. (a) Banini, S. R.; Turner, M. R.; Cummings, M. M.; Söderberg, B. C. G. Tetrahedron 2011, 67, 3603; (b) Madapa, S.; Singh, V.; Batra, S. Tetrahedron 2006, 62, 8740; (c) Lee, K. Y.; Kim, J. M.; Kim, J. N. Tetrahedron 2003, 59, 385; (d) Basavaiah, D.; Reddy, B. S.; Badsara, S. S. Chem. Rev. 2010, 110, 5447.

14. Raczyńska, E. D.; Kosińska, W.; Ośmiałowski, B.; Gawinecki, R. Chem. Rev. 2005 $105,3561$.

15. Korotaev, V. Y.; Barkov, A. Y.; Slepukhin, P. A.; Kodess, M. I.; Sosnovskikh, V. Y. Mendeleev Commun. 2011, 21, 277.

16. Levy, G.C.; Lichter, R.L. Nitrogen-15 Nuclear Magnetic Resonance Spectroscopy; John Wiley and Sons, 1979, p 80.

17. Sheldrick, G. M. Acta Crystallogr., Sect. A 2008, 64, 112 